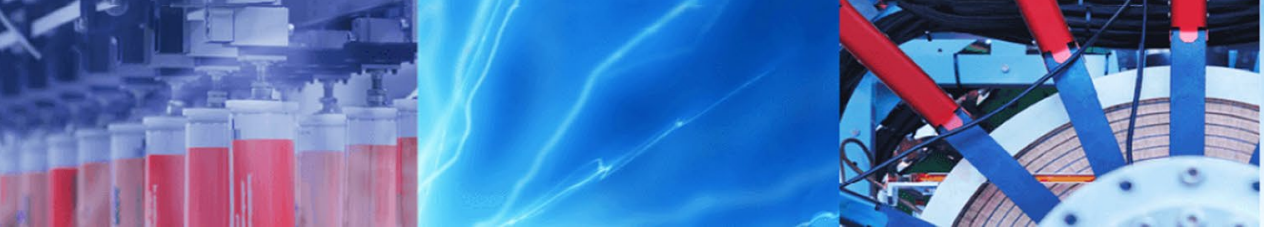

Research Article

\title{
Biodiesel production from slaughter wastes of broiler chicken: a potential survey in Iran
}

\author{
Zahra Faraji Mahyari $^{1} \cdot$ Zeinab Khorasanizadeh $^{1} \cdot$ Majid Khanali $^{1} \cdot$ Khadijeh Faraji Mahyari $^{1}$ (i)
}

Received: 26 May 2020 / Accepted: 21 December 2020 / Published online: 10 January 2021

(c) The Author(s) 2021 OPEN

\begin{abstract}
Biodiesel is a kind of biofuels that can be mixed with diesel and used as fuel. Selecting cheap and available feedstock is a prominent step in producing biodiesel economically. This paper presents the pros and cons of biodiesel and its production methods. The diesel demand is significantly high in Iran, especially in the transportation sector; On the other hand, the amount of produced waste is significant in chicken slaughterhouses. Considering this type of feedstock as a source to produce biodiesel not only can reduce the associated environmental problems, but also can supply some of the diesel needs. Hence, this paper also estimates biodiesel production potential from poultry slaughter waste and its cost. Based on the results, 736 kilotonnes of poultry slaughter waste is produced annually in Iran, which can be used as feedstock to produce 112 million liters of biodiesel by transesterification process with the production cost of around 14,277 rial/ liter; i.e. 30\% of diesel demand in the transportation sector can be supplied by B2 ( $98 \%$ diesel and $2 \%$ biodiesel) or diesel demand growth in this sector converted to B20 to increase economical and environmental sustainability.
\end{abstract}

Keywords Biodiesel $\cdot$ Chicken fat oil $\cdot$ Cost estimation $\cdot$ Production potential $\cdot$ Transesterification process

\section{Introduction}

The total global energy consumption has been rising due to the population growth, industrialization and increase of the living standards level. In 2017, the world total energy consumption was 609.5 quadrillion Btu and it is expected to reach 910.7 quadrillion Btu in 2050 with $49 \%$ growth rate [1]; More than $80 \%$ of the world energy demands are supplied by non-renewable fossil fuels (natural gas, crude oil and coal) [2]. This increasing trend, not only causes a serious crisis in energy supply, but also leads to numerous environmental issues such as climate change and global warming, caused by greenhouse gases emissions [3]. Renewable and non-fossil fuels could be a great alternative to solve this problem. In $2017,14.6 \%$ of total world energy consumption was supplied by renewable energies [4]. The use of biofuels is growing as an option in developed countries. In 2017, $1.0 \%$ of the total global energy consumption was provided by biofuels which is equivalent to $6.8 \%$ of total renewable energies [4].

Iran is a developing country located in the Middle East, with a population of about 80 million and highly dependent on low-price fossil fuels [3, 5]. In 2017, the total primary energy consumption was 285.7 Mtoe (million tonnes of oil equivalent, 1 Mtoe $=41,868,000 \mathrm{GJ}$ ), more than $90 \%$ of which was supplied by crude oil and natural gas resources as indicated in the Fig. 1 [6]. In this year, 217 million liters/ day of various types of petroleum products were consumed in Iran, 38\% of which (equals to 30,277 million liters/year) was diesel. This presents $90 \%$ of total diesel production in Iran, about 2394 million liters of which has been exported this year (Fig. 1); However, compared to the previous year, diesel consumption has been reduced in all sectors while is increased in the transport sector (the second largest part in

Khadijeh Faraji Mahyari, farajimahyari@ut.ac.ir| ${ }^{1}$ Department of Agricultural Machinery Engineering, Faculty of Agricultural Engineering and Technology, College of Agriculture and Natural Resources, University of Tehran, P.O. Box 4111, 31587-77871 Karaj, I. R. of Iran. 
Fig. 1 Primary energy consumption of Iran by carriers and sectors, $2017[6,7]$

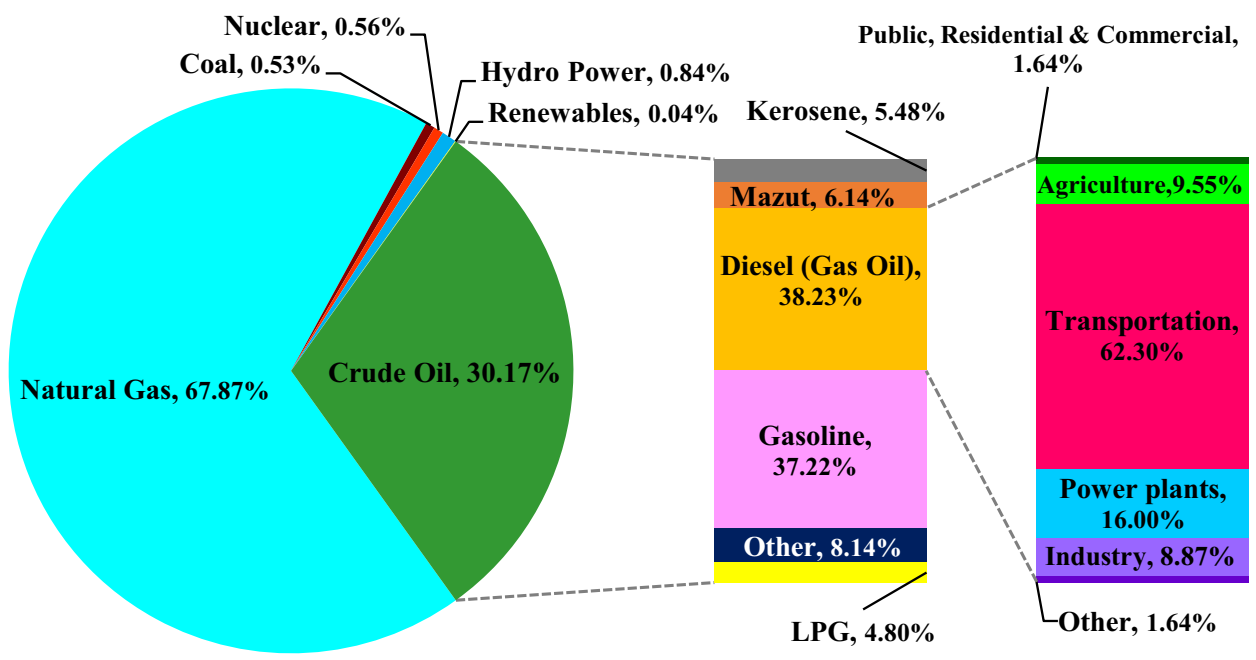

energy consumption and the largest diesel consumer in Iran) with a growth rate of $2.6 \%$ [7]. In 2017, $72 \%$ of suspended particulate matter (SPM), $34 \%$ of Nitrogen oxides $\left(\mathrm{NO}_{\mathrm{x}}\right)$ and $58 \%$ of Sulphur oxides $\left(\mathrm{SO}_{\mathrm{x}}\right)$ emissions, were released due to diesel consumption in the energy sector of Iran [7]. In other words, 8.2, 16.9 and 10.6 tonnes of SPM, $\mathrm{NO}_{\mathrm{x}}$ and $\mathrm{SO}_{\mathrm{x}}$ are produced per million liters of diesel consumption, respectively. These contaminants are the basic factors to corrosion, acid rain, and damages to trees and plants. In addition, diesel combustion and its greenhouse gases emissions cause reduction in visibility and ground-level ozone. Furthermore, organic compounds coming out of diesel engines exhaust contain carcinogens like nitro- polyaromatic hydrocarbons [8]. Therefore, the consumption of this petroleum product is the main cause of the most dangerous pollutants emissions in Iran which should be replaced by non-carbon biofuels such as biodiesel. Studying biodiesel production methods, as a carbon-neutral fuel can be certainly an important stride in substituting this clean energy with diesel. The potential assessment can support planning for the sustainable development of the bioenergy system.

The first purpose of this paper is to evaluate the various feedstocks as well as explain a brief overview of the technologies currently used for biodiesel production. The second purpose is to assess the potential of biodiesel production and consumption from chicken fat as feedstock and its cost in Iran, which research methodology is described in Sect. 3. According to the results and discussion, Sect. 4 concluded weather biodiesel is an acceptable and sustainable alternative for diesel in Iran or not?

\section{Biodiesel: feedstocks and production methods}

The mono-alkyl ester of long chain fatty acid is called biodiesel. It is a renewable alternative for the petroleumderived diesel which has non-renewable nature $[9,10]$. The impressive features of biodiesel made it acceptable in the energy market. However, it is worth noting that these biofuels have some disadvantages too. The pros and cons of biodiesel is tabulated in Table 1 [8-14].

Figure 2 shows the world's largest producing countries in 2017. In this year, U.S. was the largest biodiesel producer in the world, generating 6 billion liters; To produce this amount of biodiesel, in U.S. during 2017, various feedstocks were used, including soybean oil (52\%), recycled feeds (13\%), corn oil (13\%), canola oil (12\%) and animal fats (10\%) [15].

One of the major challenges in biodiesel production is the supply of raw materials, because more than $70 \%$ of the total cost of biodiesel production depends on it. Another challenge is the availability of feedstock which depends on various factors, including the geographical conditions of the region and the nature of the oil resources. In general, biodiesel is divided into five types based on feedstock that are introduced and discussed in Table 2 [8-10, 16-20]. Currently, more than $95 \%$ of biodiesel production in the world is based on 1 st generation feedstocks that are commonly used in rich countries in terms of agricultural land and water resources. However, 
Table 1 Advantages and disadvantages of biodiesel in contrast with diesel

\begin{tabular}{|c|c|}
\hline Advantages & Disadvantages \\
\hline Renewability $[9,11,12,14]$ & More expensive [11] \\
\hline Local production [10-12] & Lower oxidation stability $[9,10]$ \\
\hline More cost efficient & Corrosion of the fuel tank, pipe and injector \\
\hline Higher biodegradable $[11,14]$ & Higher copper and brass strip corrosion $[11,12,14]$ \\
\hline Non-flammable and non-toxic $[11,12,14]$ & $\begin{array}{l}\text { Fuel system blockage, seal failures, filter clogging and deposit at } \\
\text { injection pump }\end{array}$ \\
\hline Lower noxious fumes and odors [12] & Lower volatility $[10,14]$ \\
\hline Higher cetane number $[10,14]$ & Higher required injector pressure \\
\hline Lower ignition delay & Incomplete combustion \\
\hline Lower vapour pressure and higher flash point $[10,11,14]$ & Higher cloud and pour point $[10,12,14]$ \\
\hline Safe transportation, handling, distribution, utilization and storage & Unfeasible for cold climates \\
\hline Better lubricating quality [10-13] & Higher viscosity (11-18 times) $[10,12]$ \\
\hline Lower engine wear & $\begin{array}{l}\text { More difficult pumping, combustion and atomization in the injec- } \\
\text { tor system of a diesel engine }\end{array}$ \\
\hline Higher engine efficiency & Development of gumming \\
\hline Without the need for additional lubricant & Ring sticking \\
\hline Lower sulfur content $[8,14]$ & Higher density $[11,13]$ \\
\hline $78 \%$ lower net $\mathrm{CO}_{2}$ emission $[9,10,14]$ & Need to use the blends in sub-freezing conditions \\
\hline $20 \%$ lower hydrocarbons (HC) [8] & $2 \%$ lower brake thermal efficiency $[8]$ \\
\hline $90 \%$ lower total unburned $\mathrm{HC}[8]$ & $13 \%$ higher specific fuel consumption [8] \\
\hline $75-90 \%$ lower polycyclic aromatic HC [8] & $12 \%$ lower energy content $[10,13,14]$ \\
\hline $30 \%$ lower carbon monoxide (CO) [8] & $2-10 \%$ higher fuel consumption \\
\hline $50 \%$ lower smoke $[8]$ & Necessity of engine modification for higher blends $[10,12,14]$ \\
\hline Lower $\mathrm{SO}_{2}$, and PM emissions [12] & $10-11 \%$ higher oxygen content $[10,14]$ \\
\hline No required engine modification up to $B 20[10,12,14]$ & Advance in fuel injection and timing \\
\hline $10-11 \%$ higher oxygen content $[10-12,14]$ & Earlier start of combustion \\
\hline Higher combustion efficiency & $10-14 \%$ higher $\mathrm{NO}_{x}$ emission \\
\hline
\end{tabular}

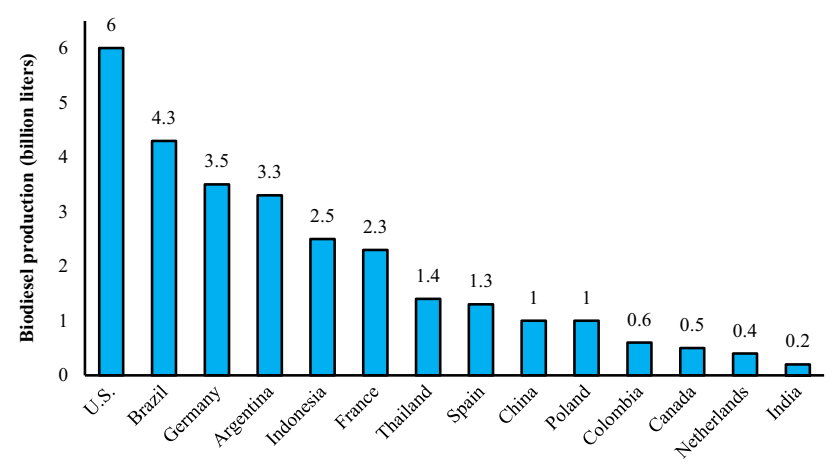

Fig. 2 Biodiesel production in different countries, 2017 [4]

producing this type of biodiesel results in increasing land use change (LUC) and reducing land allocation for cultivation of food crops, leading to food shortages and price increase [21-23]. The 2 nd generation of biodiesel production does not compete with food production plans but affects LUC criterion. In addition, the use of chemical fertilizers, irrigation and harvesting is inevitable in order to achieve the maximum yield of 2 nd generation feedstocks. The approach of using waste sources (waste oil produced from the consumption of edible oil and animal waste) for biodiesel production not only avoids the extra cost and environmental problems but also eliminates competition for food, water and land. In addition, it ensures the supply of feedstocks for biodiesel production thanks to their variety and plenitude [24]. Extensive research directed on biodiesel production from 4th and 5 th generation feedstocks that showed production cost is high compared to petroleum-derived diesel. Therefore, only 3 rd generation biodiesel production is possible in viewpoint of cost and feedstock sustainability.

However, the direct use of pure oil from these types of feedstocks are not satisfactory and practical in diesel engines as it results in polymerization during storage and combustion and, subsequently, gum formation, carbon deposit and incomplete combustion, due to its high viscosity, acid composition and free fatty acid content. To resolve this problem, either pure oil needs to be diluted or its hydrocarbon chains have to be broken down into 
Table 2 Biodiesel feedstock classification based on the sustainability issue

\begin{tabular}{|c|c|c|c|c|}
\hline Type of biodiesel & Feedstocks & Examples & Consequences & References \\
\hline Fossil fuel & Mineral diesel & - & $\begin{array}{l}\text { Finite unsustainable reserves } \\
\text { Deep GHG footprint } \\
\text { Toxic pollutants } \\
\text { Causing acid rain }\end{array}$ & {$[8]$} \\
\hline 1st generation & Edible oil crops & $\begin{array}{l}\text { Palm, rapeseed, sunflower, soybean, } \\
\text { Linseed, Cotton seed }\end{array}$ & $\begin{array}{l}\text { Land use change } \\
\text { GHG footprint } \\
\text { Food competition } \\
\text { High cost of feedback/biodiesel }\end{array}$ & {$[8-10,16-19]$} \\
\hline 2nd generation & $\begin{array}{l}\text { Non-edible oil crops/ligno- } \\
\text { cellulosic residues }\end{array}$ & $\begin{array}{l}\text { Jatropha, camelina, pongamia, } \\
\text { neem, rice straw, castor oil }\end{array}$ & $\begin{array}{l}\text { Land and water usage } \\
\text { GHG footprint } \\
\text { Fertilizer and pesticides }\end{array}$ & {$[8-10,16-19]$} \\
\hline 3rd generation & $\begin{array}{l}\text { Waste } \\
\text { Industrial and commercial } \\
\text { waste } \\
\text { Animal waste }\end{array}$ & $\begin{array}{l}\text { Food waste, used cooked oil, sew- } \\
\text { age waste } \\
\text { Fish oil, tallow, poultry fat }\end{array}$ & $\begin{array}{l}\text { No GHG footprint } \\
\text { No land/water use } \\
\text { Low cost sustainable feedstock } \\
\text { Solution for waste disposal } \\
\text { No food competition }\end{array}$ & {$[8,10,16-20]$} \\
\hline 4th generation & $\begin{array}{l}\text { Algae } \\
\text { Microalgae } \\
\text { Macroalgae }\end{array}$ & $\begin{array}{l}\text { Chlorella vulgaris, Nannochloro- } \\
\text { psis sp., Arthrospira platensis, } \\
\text { Arthrospira maxima } \\
\text { Cladophora fracta }\end{array}$ & $\begin{array}{l}\text { No GHG footprint } \\
\text { No land/water use } \\
\text { No food competition } \\
\text { Sustainable feedstock in long term }\end{array}$ & {$[8-10,17,18]$} \\
\hline 5 th generation & Genetically engineered crops & - & $\begin{array}{l}\text { No GHG footprint } \\
\text { No land/water use } \\
\text { No food competition } \\
\text { Sustainable feedstock in long term }\end{array}$ & {$[8,17]$} \\
\hline
\end{tabular}

simpler components. It can be performed in several methods: physical methods, including direct use and blending (dilution) and microemulsion; and chemical methods, including pyrolysis (thermal cracking) and transesterification (alcoholysis). Today, transesterification is the most common method used in industry [25-28]. The comparison of these four main techniques is shown in Table $3[12$, $17,19,29-40]$.

\section{Materials and methods}

\subsection{Feedstock}

Chicken slaughterhouse wastewater is often discharged directly (untreated) to municipal wastewater or in most cases to surface water sources and their solid waste is also usually burned or buried. These disposal methods will result in environmental pollution as outflows in the slaughterhouse industry have a lot of BOD (Biochemical Oxygen Demand) and COD (Chemical Oxygen Demand). In addition, the presence of pathogenic microorganisms in this waste type results in its decomposition into the environment and odor production and uncontrolled greenhouse gas emissions to the atmosphere; Consequently, it threatens the health of residents near disposal sites.
It is proved that chicken fat is a promising feedstock for biodiesel production [14, 41, 42]; Although slaughter waste requires pre-processing, compared to low fatty acid sources. It is considered as one of the cheapest industrial products to produce biodiesel [43-45]. Furthermore, the amount of non-edible oil produced from chicken fat extraction is by far more than the related counterpart for vegetable oil; Rendering it is more cost-effective compared to the other feedstock. Chicken oil contains high energy content (Its calorific value is $39.4 \mathrm{MJ} / \mathrm{kg}$ [46], which is just a bit lesser than that of petroleum fuel). In biodiesel production, The highest yield has been acquired from chicken fat (approximately 99.1\% [42]) in comparison with other types of biodiesel feedstock and it can be used as a solvent to improve alcohol and diesel properties (since it is more lubricant than petroleum diesel) $[11,47-49]$. In this paper, the potential and cost of biodiesel production from chicken fat is investigated in Iran.

\subsection{Calculation of biodiesel production potential from chicken fat}

In Iran, there is no accurate data on the amount of produced waste in poultry slaughterhouses. Only, there are some statistics on the number of chickens and live chicken weight. The 2017 statistics, separated by province, are presented in Table 4 [50]. 


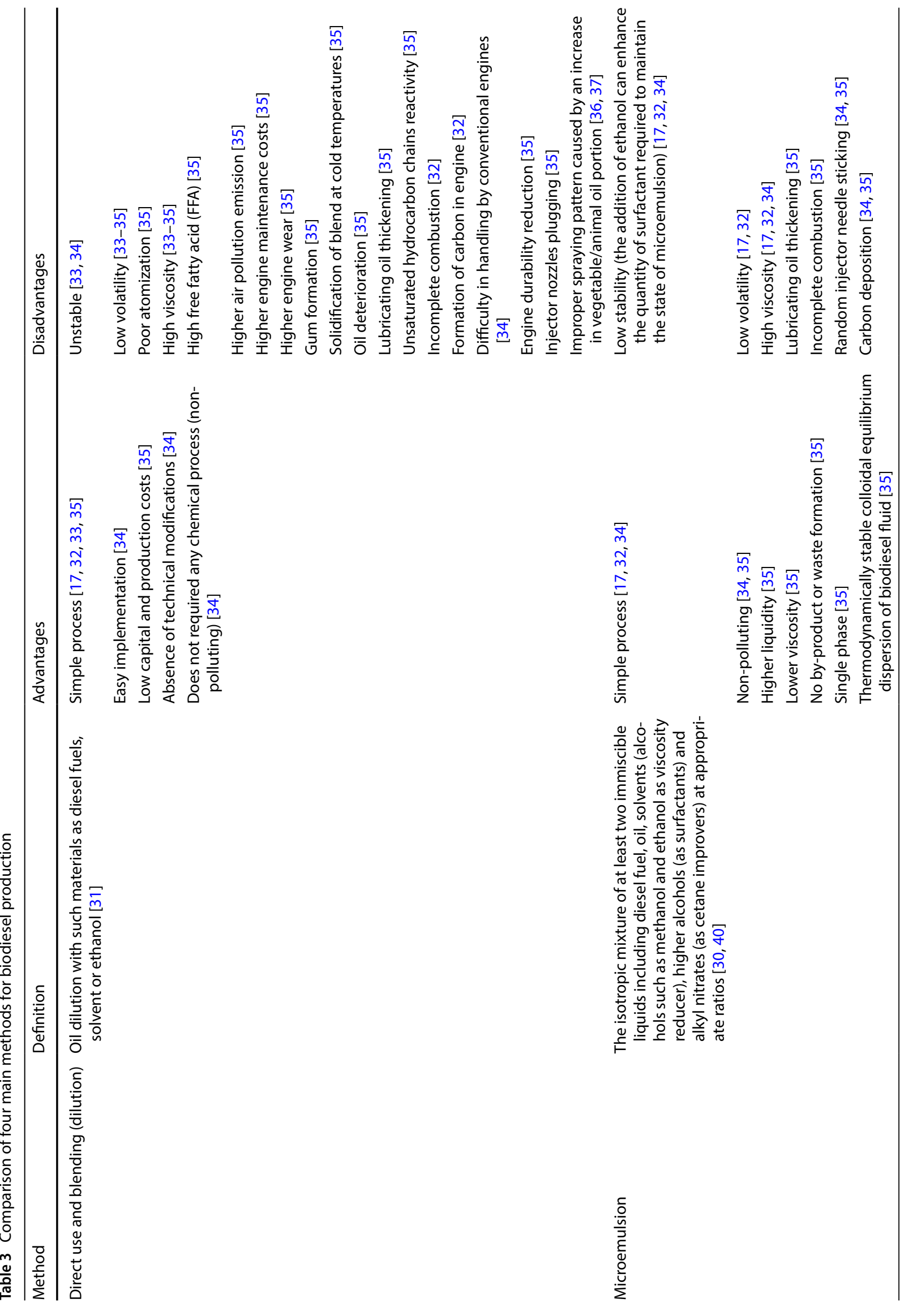




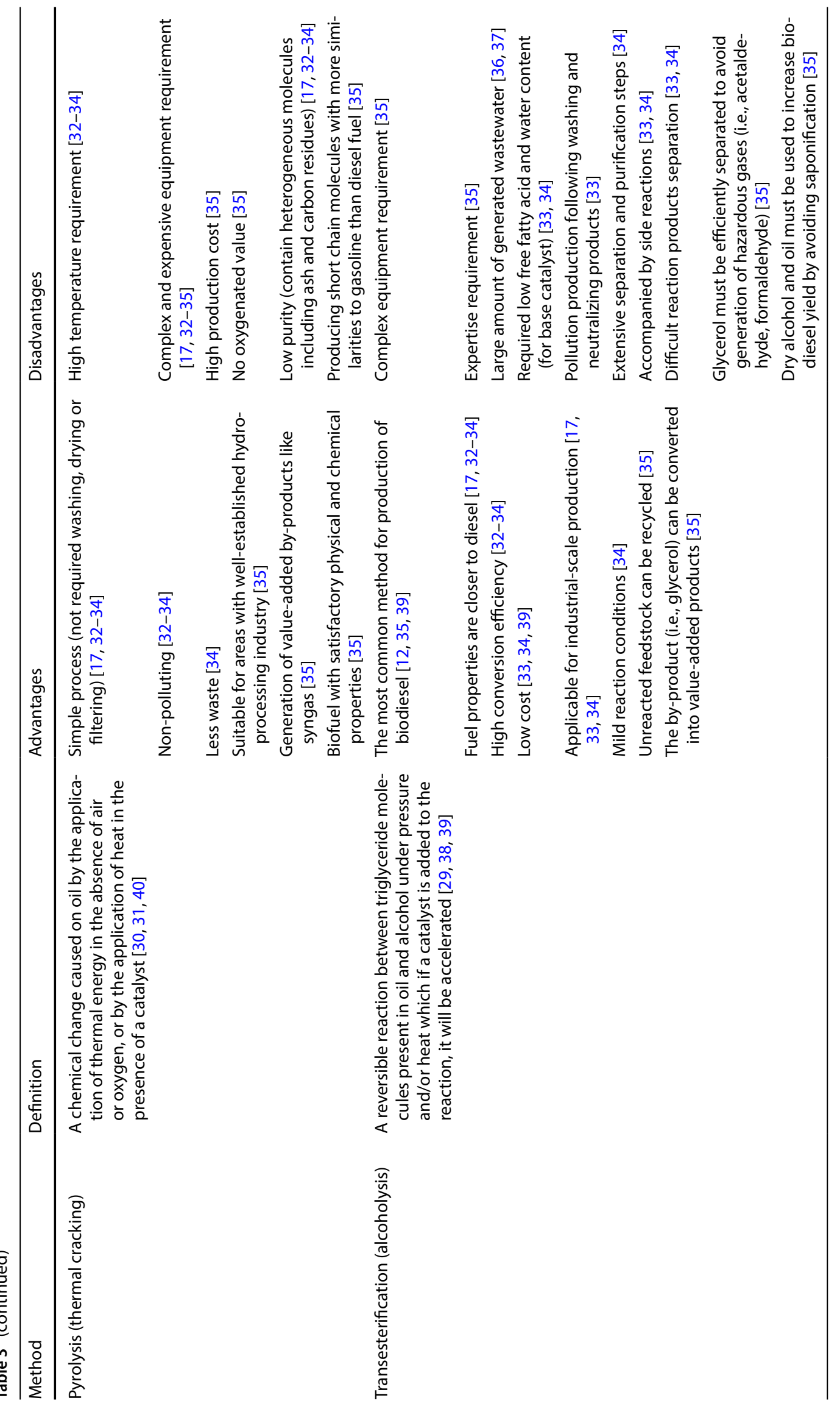

SN Applied Sciences 
The amount of slaughter waste production in each region varies based on feeding conditions, the number and type of slaughter as well as the percentage of waste from each animal; However, at least $28 \%$ of the weight of a live broiler chicken constitutes solid waste $[51,52]$ (Table 5). 35\% of the waste is converted to high protein meal and $1.09 \mathrm{~kg}$ of Chicken fat oil (with density equal to $0.87 \mathrm{~kg} / \mathrm{l}$ ) can be extracted by rendering $7.5 \mathrm{~kg}$ waste [53]. Efficiency of converting chicken fat oil to biodiesel is $88.1 \%$ by transesterification process in the presence of homogeneous alkaline catalyst $\mathrm{KOH}$. Finally, according to all these, the potential of biodiesel production is calculated for broiler slaughter waste $[42,54]$.

\subsection{Estimation of the cost of biodiesel production from chicken fat}

Chicken fat is a by-product in the rendering process of chicken slaughter waste for meal preparation (Fig. 3). So, it is free and only the cost of collection and transportation is considered.

In this paper, the transesterification process with methanol as alcohol (due to its low cost, better physical and chemical properties and easy removal from glycerin) and $\mathrm{KOH}$ as catalyst (due to its low cost, high catalytic activity and mild operating conditions) were considered to estimate the cost of biodiesel production from chicken fat $[41,54,55]$; The
Table 4 Amount of live broiler chicken produced in each province in Iran according to the data in 2017 [50]

\begin{tabular}{|c|c|c|}
\hline Province & $\begin{array}{l}\text { Weight of live poultry } \\
\text { (tonne) }\end{array}$ & $\begin{array}{l}\text { Number of one-day old } \\
\text { broiler chick ( } 1000 \text { pieces) }\end{array}$ \\
\hline East Azarbaijan & 95,331 & 35,661 \\
\hline West Azarbaijan & 91,980 & 40,127 \\
\hline Ardabil & 34,901 & 14,917 \\
\hline Isfahan & 176,246 & 78,821 \\
\hline Alborz & 9272 & 4564 \\
\hline Ilam & 43,851 & 18,759 \\
\hline Bushehr & 31,696 & 15,945 \\
\hline Tehran & 18,584 & 7672 \\
\hline Chaharmahal and Bakhtiari & 24,085 & 10,538 \\
\hline South Khorasan & 62,424 & 31,545 \\
\hline Razavi Khorasan & 200,238 & 87,629 \\
\hline North Khorasan & 17,975 & 8094 \\
\hline Khuzestan & 92,654 & 46,055 \\
\hline Zanjan & 44,171 & 18,058 \\
\hline Semnan & 61,898 & 25,221 \\
\hline Sistan and Baluchestan & 23,801 & 12,607 \\
\hline Fars & 167,201 & 78,575 \\
\hline Qazvin & 64,905 & 26,122 \\
\hline Qom & 32,054 & 13,270 \\
\hline Kordestan & 99,665 & 39,927 \\
\hline Kerman & 51,580 & 23,598 \\
\hline Kermanshah & 54,691 & 23,359 \\
\hline Kohgiluyeh and Boyer-Ahmad & 11,107 & 5204 \\
\hline Golestan & 230,485 & 95,257 \\
\hline Gilan & 190,818 & 83,410 \\
\hline Lorestan & 83,695 & 35,889 \\
\hline Mazandaran & 317,334 & 132,045 \\
\hline Markazi & 62,545 & 26,989 \\
\hline Hormozgan & 29,205 & 15,094 \\
\hline Hamedan & 55,008 & 21,613 \\
\hline Yazd & 60,361 & 28,353 \\
\hline Total & $2,539,761$ & $1,104,918$ \\
\hline
\end{tabular}


Table 5 Poultry slaughter wastes and their potential uses [51, 52]

\begin{tabular}{lll}
\hline Type of waste & \% of live weight & Uses \\
\hline Feathers & $7-8$ & $\begin{array}{c}\text { Bedding material, decorative purpose, sporting equipment, manure or fertilizers } \\
\text { and feather meal }\end{array}$ \\
Heads & $2.5-3$ & $\begin{array}{l}\text { Poultry meal } \\
\text { Blood }\end{array}$ \\
Gizzard and proventriculus & $3.2-3.7$ & Edible and source of chitinolytic enzyme \\
Feet & $3.5-4.2$ & Soup and technical fat/poultry grease \\
Intestines and glands & $8.5-9$ & Gat sport, meat meal, poultry grease and active principles (hormones and enzymes)
\end{tabular}

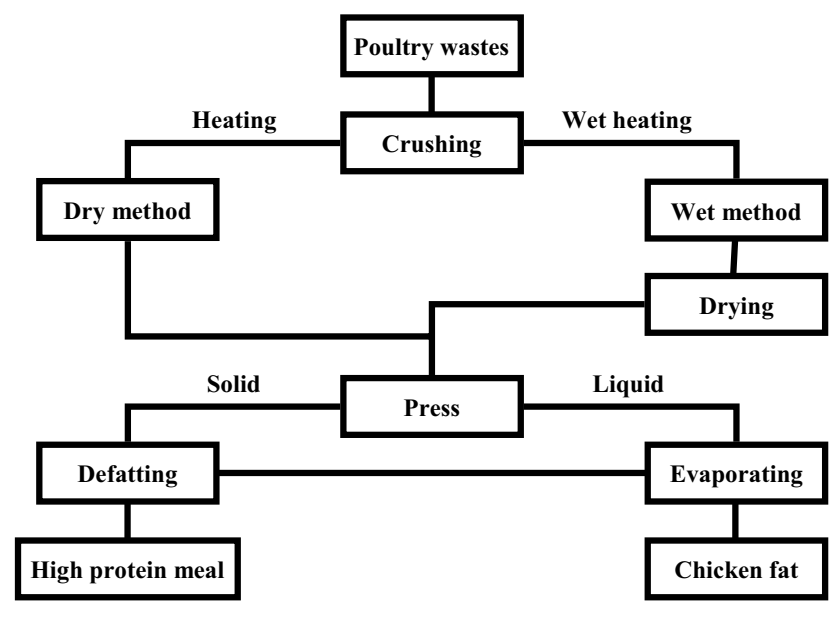

Fig. 3 Rendering process of poultry wastes [42], with permission from "Elsevier" Copyright $\odot 2020$

most important parameters of this process are: reaction temperature, alcohol to oil ratio, type and amount of catalyst, mixing intensity and type of raw oil. The various stages of the process are shown in Fig. 4 [54]. Chicken fat is slowly melted and then filtered. $1000 \mathrm{ml}$ of chicken fat oil is poured into a volumetric flask; volumetric flask is manually shaked and simultaneously heated. When the raw oil temperature reaches $60^{\circ} \mathrm{C}$, methanol $(200 \mathrm{ml})$ and $\mathrm{KOH}$ solution $(7.5 \mathrm{~g})$ are added separately to the oil and the volumetric flask door is closed. Then, the solution is stirred at high speeds. The temperature should not exceed $60^{\circ} \mathrm{C}$ as methanol evaporates, if temperature passes $60^{\circ} \mathrm{C}$. This solution is stirred for an hour and transferred to a separating glass conical flask. Upon separation, biodiesel accumulated at the top and glycerin at the bottom. By opening the valve, the conical flask is cleared from the glycerin. At this time, the biodiesel is repeatedly washed with distilled water at $50^{\circ} \mathrm{C}$ to clean the soap thoroughly. Finally, it is heated to temperature above $100{ }^{\circ} \mathrm{C}$ to evaporate the water. The result is ready-to-use chicken fat biodiesel. The data and assumptions needed to estimate the net cost of biodiesel production are presented in Table 6.

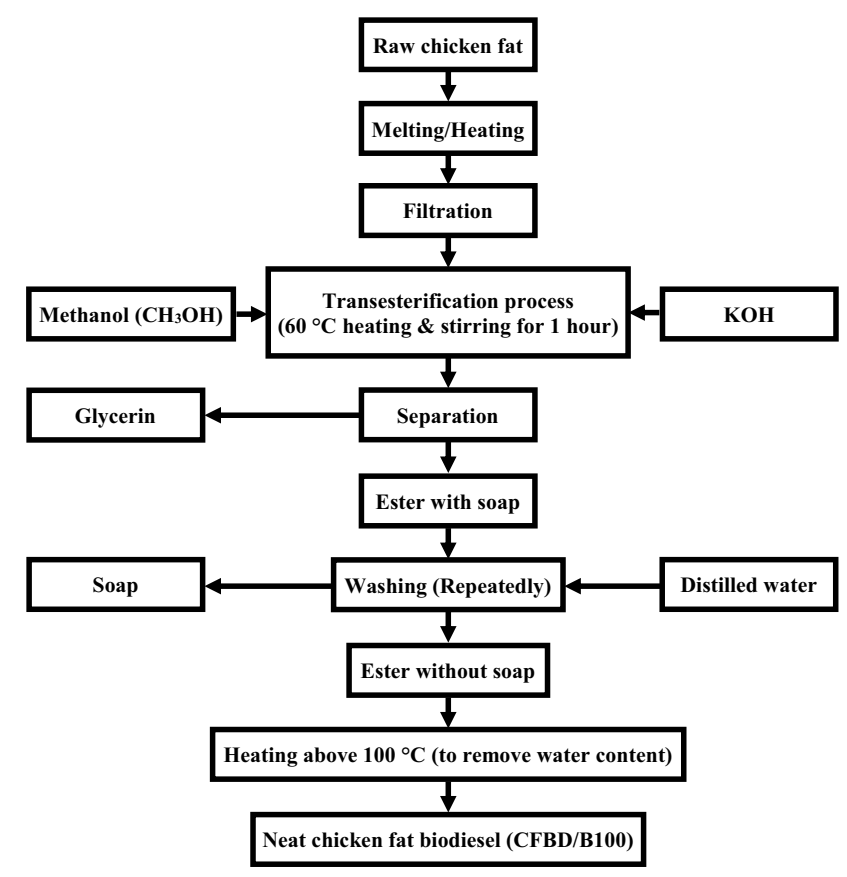

Fig. 4 Various stages of chicken fat biodiesel production by transesterification process [54]

\section{Results and discussion}

In $2017,2,539,761$ tonne live chickens were bred per $1,104,918,000$ chickens in Iran ( $2.30 \mathrm{~kg}$ per chicken). The amount of poultry slaughter waste was estimated at $7.632 \times 10^{5}$ tonne. Figure 5 shows the amount of waste generated based on its type. $2.671 \times 10^{5}$ tonne of high protein meals and $110.918 \times 10^{3}$ tonne of chicken fat oil can be obtained from this produced waste.

The potential of biodiesel production is given for each province in Table 7. Based on these results, 127.492 million liters of chicken fat oil can be produced with the potential of producing 112.321 million liters of biodiesel in Iran. The highest contributions are determined for the provinces of Mazandaran (12.49\%), Golestan (9.08\%), Razavi Khorasan (7.88\%), Gilan (7.51\%), Isfahan (6.49\%), and Fars (6.58\%). 
Table 6 Data and assumptions for net cost estimation of biodiesel production from chicken fat

\begin{tabular}{|c|c|c|}
\hline Data and assumptions & Value & Unit \\
\hline Consumption chicken fat & 1000 & liter/day \\
\hline Requirement of methanol & 200 & liter/day \\
\hline Requirement of $\mathrm{KOH}$ & 7.5 & kg/day \\
\hline Requirement of water & 4000 & kg/day \\
\hline Price of chicken fat & 0 & rial/liter \\
\hline Price of collection and transportation and melting chicken fat & 6000 & rial/liter \\
\hline Price of methanol & 24,000 & rial/liter \\
\hline Price of $\mathrm{KOH}$ & 180,000 & $\mathrm{rial} / \mathrm{kg}$ \\
\hline Price of electricity & 720 & $\mathrm{rial} / \mathrm{kWh}$ \\
\hline Basic temperature & 20 & ${ }^{\circ} \mathrm{C}$ \\
\hline Power of motor for Stirring methanol and $\mathrm{KOH}$ & 10 & kW \\
\hline Power of motor for Stirring during transesterification process & 15 & kW \\
\hline Duration of stirring methanol and $\mathrm{KOH}$ & 15 & $\min /$ day \\
\hline Duration of Stirring during transesterification process & 1 & h/day \\
\hline Efficiency & 0.9 & - \\
\hline Maintenance of temperature about $60^{\circ} \mathrm{C}$ & 600,000 & $\mathrm{rial} / \mathrm{month}$ \\
\hline Specific heat of waste chicken fat & 1.97 & $\mathrm{~kJ} / \mathrm{kgK}$ \\
\hline Specific heat of water & 4.18 & $\mathrm{~kJ} / \mathrm{kgK}$ \\
\hline First cost of equipment & $300,000,000$ & rial \\
\hline Equipment life & 15 & year \\
\hline Interest rate & 0.1 & - \\
\hline Labor cost & $27,000,000$ & $\mathrm{rial} / \mathrm{month}$ \\
\hline Rent & $3,000,000$ & $\mathrm{rial} / \mathrm{month}$ \\
\hline Maintenance & 600,000 & $\mathrm{rial} / \mathrm{month}$ \\
\hline Glycerin produced & 50 & liter/day \\
\hline Price of glycerin & 15,000 & rial/liter \\
\hline
\end{tabular}

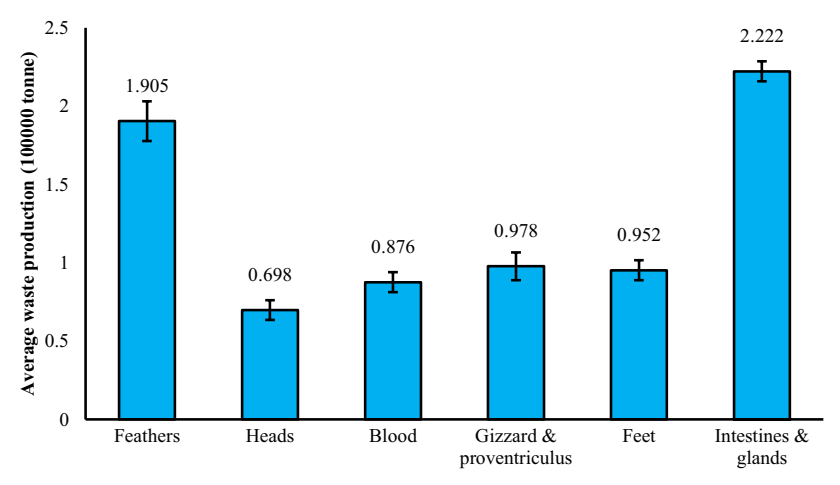

Fig. 5 Estimated average quantities of produced waste from poultry slaughter in Iran, 2017

In other words, these Six provinces can produce approximately half of the total biodiesel production potential from slaughter wastes in Iran. This amount of biodiesel production potential is equal to $0.6 \%$ of consumed diesel in the transportation sector in 2017. By managing that, 561.602 million liters of B20 (80\% diesel and 20\% biodiesel) can be replaced with required diesel for transportation, which is approximately equivalent to increasing diesel consumption in this sector compared to 2016; Or supplying $30 \%$ of diesel consumption in the transportation sector as B2 ( $98 \%$ diesel and $2 \%$ biodiesel). This will be efficient for reducing the emission of pollutants, especially $\mathrm{SPM}$ and $\mathrm{SO}_{\mathrm{x}}$. Although the potential of biodiesel production from edible oilseeds is estimated at 721 million liters [56], oilseeds are consumed only in the food sector in Iran. Also, using poultry slaughter waste to produce biodiesel can solve the problem of disposal.

The annual cost was estimated to produce biodiesel from 1000 L/day of chicken fat (as feedstock consumption); The results of cost evaluation are presented in Table 8. Despite the use of free feedstock (chicken fat), these results show that $90 \%$ of the biodiesel production cost is related to raw materials (collection and transportation and melting chicken fat, Methanol and $\mathrm{KOH}$ ), $51 \%$ of which is related to chemicals. Income comes around 270 million rial/year from producing glycerin, which can cover $6 \%$ of biodiesel production cost. Therefore, the net cost of biodiesel production is 4590.889 million rial/year equals 14,277 rial/lite from chicken fat. According to the declaration of the National Iranian Oil Refining and Distribution Company (NIORDC), the price of diesel is 3000 rials [57] 
Table 7 Amount of produced waste from broiler chicken slaughter and its biodiesel potential in each province of Iran according to the data in 2017

\begin{tabular}{|c|c|c|c|c|}
\hline Province & Average wastes (ton) & High protein meal (ton) & $\begin{array}{l}\text { Chicken fat oil (mil- } \\
\text { lion liters) }\end{array}$ & $\begin{array}{l}\text { Biodiesel } \\
\text { (million } \\
\text { liters) }\end{array}$ \\
\hline East Azarbaijan & $28,646.966$ & $10,026.438$ & 4.785 & 4.216 \\
\hline West Azarbaijan & $27,639.990$ & 9673.997 & 4.617 & 4.068 \\
\hline Ardabil & $10,487.751$ & 3670.713 & 1.752 & 1.543 \\
\hline Isfahan & $52,961.923$ & $18,536.673$ & 8.847 & 7.794 \\
\hline Alborz & 2786.236 & 975.183 & 0.465 & 0.410 \\
\hline Ilam & $13,177.226$ & 4612.029 & 2.201 & 1.939 \\
\hline Bushehr & 9524.648 & 3333.627 & 1.591 & 1.402 \\
\hline Tehran & 5584.492 & 1954.572 & 0.933 & 0.822 \\
\hline Chaharmahal and Bakhtiari & 7237.543 & 2533.140 & 1.209 & 1.065 \\
\hline South Khorasan & $18,758.412$ & 6565.444 & 3.134 & 2.761 \\
\hline Razavi Khorasan & $60,171.519$ & $21,060.032$ & 10.052 & 8.855 \\
\hline North Khorasan & 5401.488 & 1890.521 & 0.902 & 0.795 \\
\hline Khuzestan & $27,842.527$ & 9744.884 & 4.651 & 4.098 \\
\hline Zanjan & $13,273.386$ & 4645.685 & 2.217 & 1.953 \\
\hline Semnan & $18,600.349$ & 6510.122 & 3.107 & 2.737 \\
\hline Sistan and Baluchestan & 7152.201 & 2503.270 & 1.195 & 1.053 \\
\hline Fars & $50,243.901$ & $17,585.365$ & 8.393 & 7.394 \\
\hline Qazvin & $19,503.953$ & 6826.383 & 3.258 & 2.870 \\
\hline Qom & 9632.227 & 3371.279 & 1.609 & 1.418 \\
\hline Kordestan & $29,949.333$ & $10,482.266$ & 5.003 & 4.408 \\
\hline Kerman & $15,499.790$ & 5424.927 & 2.589 & 2.281 \\
\hline Kermanshah & $16,434.646$ & 5752.126 & 2.745 & 2.419 \\
\hline Kohgiluyeh and Boyer-Ahmad & 3337.654 & 1168.179 & 0.558 & 0.491 \\
\hline Golestan & $69,260.743$ & $24,241.260$ & 11.570 & 10.193 \\
\hline Gilan & $57,340.809$ & $20,069.283$ & 9.579 & 8.439 \\
\hline Lorestan & $25,150.348$ & 8802.622 & 4.201 & 3.701 \\
\hline Mazandaran & $95,358.867$ & $33,375.603$ & 15.930 & 14.034 \\
\hline Markazi & $18,794.773$ & 6578.170 & 3.140 & 2.766 \\
\hline Hormozgan & 8776.103 & 3071.636 & 1.466 & 1.292 \\
\hline Hamedan & $16,529.904$ & 5785.466 & 2.761 & 2.433 \\
\hline Yazd & $18,138.481$ & 6348.468 & 3.030 & 2.669 \\
\hline Total & $763,198.181$ & $267,119.363$ & 127.492 & 112.321 \\
\hline
\end{tabular}

per liter and the subsidy is paid more than 65,500 rials per liter of diesel. The use of biodiesel can reduce subsidies. Also, consuming biodiesel instead of diesel can reduce external cost.

\section{Conclusion}

The growing need for new sources of energy has become a major problem in recent years. This energy crisis has led to widespread use of exhaustible and non-renewable fossil fuel resources and severe environmental problems. Therefore, replacing fossil fuel sources with renewable biofuels is essential for achieving sustainable development, environmental protection and controlling greenhouse gas emissions. Biodiesel is known as an alternative fuel for diesel. In addition to reviewing feedstock types and biodiesel production methods, this paper evaluated the potential of biodiesel production from slaughter wastes of broiler chicken. According to the results, in 2017, 763 kilotonnes of poultry slaughter waste was produced in Iran; The biodiesel production potential was estimated at 112 million liters from this source that Mazandaran province has the highest potential for producing biodiesel with 14 million liters per year. The results of this study show that we can supply $30 \%$ of the diesel demand in the transportation sector by $\mathrm{B} 2$ by this amount of biodiesel production. The cost of biodiesel production was estimated to be less than 
Table 8 Cost of biodiesel production from chicken fat

\begin{tabular}{ll}
\hline Type of cost/income & $10^{6}$ rial/year \\
\hline Cost & \\
Raw materials & 2160 \\
Chicken fat & 1728 \\
Methanol & 486 \\
$\mathrm{KOH}$ & \\
Electricity & 5.484 \\
Heating of oil from 20 to $60^{\circ} \mathrm{C}$ for transesterification process & 0.648 \\
Stirring methanol and $\mathrm{KOH}$ & 3.888 \\
Stirring during transesterification process & 7.2 \\
Maintenance of temperature about $60^{\circ} \mathrm{C}$ & 40.128 \\
Heating of water from 20 to $50^{\circ} \mathrm{C}$ for water washing & 12.340 \\
Heating of oil to $110^{\circ} \mathrm{C}$ for removing water if present & 50 \\
Equipment & 367.2 \\
Other & 4860.889 \\
Total & \\
Income & 270 \\
Glycerin production &
\end{tabular}

15,000 rial/liter from chicken fat by transesterification process with methanol and $\mathrm{KOH}$; This cost will even become minimal if socio-economic benefits like reducing pollution and employment generation are considered. In the following, it is suggested to evaluate the potential of biodiesel production from various types of animal fat waste in Iran and to identify the provinces with the highest potential. This knowledge helps to better plan for sustainable development of the bioenergy system.

Authors' contribution All authors contributed to study idea of project. Material preparation, data collection and analysis were performed by ZFM, ZK and KFM. The first draft of the manuscript was written by ZFM and edited by ZK. MK was responsible for leadership and advisement. KFM was responsible to the management and coordination for the research activity planning and execution. All authors commented on previous versions of the manuscript and approved the final manuscript.

\section{Compliance with ethical standards}

Conflict of interest The authors declare that they have no conflict of interest.

Open Access This article is licensed under a Creative Commons Attribution 4.0 International License, which permits use, sharing, adaptation, distribution and reproduction in any medium or format, as long as you give appropriate credit to the original author(s) and the source, provide a link to the Creative Commons licence, and indicate if changes were made. The images or other third party material in this article are included in the article's Creative Commons licence, unless indicated otherwise in a credit line to the material. If material is not included in the article's Creative Commons licence and your intended use is not permitted by statutory regulation or exceeds the permitted use, you will need to obtain permission directly from the copyright holder. To view a copy of this licence, visit http://creativecommons .org/licenses/by/4.0/.

\section{References}

1. EIA (2020) International Energy Outlook 2019. In: U.S. Energy Inf. Adm. https://www.eia.gov/outlooks/ieo/. Accessed 24 Aug 2020

2. Ritchie H, Roser M (2020) Fossil fuels. In: Our world data. https ://ourworldindata.org/fossil-fuels. Accessed 18 May 2020

3. Hosseini SS, Aghbashlo M, Tabatabaei M et al (2015) Thermodynamic evaluation of a photobioreactor for hydrogen production from syngas via a locally isolated Rhodopseudomonas palustris PT. Int J Hydrogen Energy 40:14246-14256. https://doi. org/10.1016/j.ijhydene.2015.08.092

4. REN21 (2019) Renewables 2019 Global Status Report (GSR), Paris, France

5. Worldometer (2020) Iran population in 2020. https://www.world ometers.info/world-population/iran-population/. Accessed 18 May 2020

6. SCI (2020) Iran statistical yearbook 2017-2018: Oil and Gas. Statistical Centre of Iran

7. $\mathrm{MoE}(2020)$ National Energy Balance of Iran in 2017

8. Khan HM, Ali CH, lqbal T et al (2019) Current scenario and potential of biodiesel production from waste cooking oil in Pakistan: an overview. Chin J Chem Eng 27:2238-2250

9. Da Silva KRN, Corazza MZ, Raposo JL (2018) Renewable energy sources: a sustainable strategy for biodiesel productions. In: Trindade M (ed) Increased biodiesel efficiency: alternatives for production, stabilization, characterization and use of coproduct. Springer, Berlin, pp 1-31

10. Bonet Ragel K, Benaiges i Massa MD, Valero Barranco F, Universitat Autònoma de Barcelona. Departament d'Enginyeria Química B i A (2018) Enzymatic synthesis of biodiesel from high free fatty acid feedstock using a recombinant Rhizopus oryzae lipase. Universitat Autònoma de Barcelona 
11. Subramaniam D, Murugesan A, Avinash A, Kumaravel A (2013) Bio-diesel production and its engine characteristics - an expatiate view. Renew Sustain Energy Rev 22:361-370

12. Hassan MH, Kalam MA (2013) An overview of biofuel as a renewable energy source: development and challenges. In: Procedia engineering, Elsevier Ltd, pp 39-53

13. Banka S, Parikh SP (2019) Nonedible oil biodiesels: the cuttingedge future of renewable energy in India. Asia-Pac J Chem Eng 14:e2310. https://doi.org/10.1002/apj.2310

14. Atabani AE, Silitonga AS, Badruddin IA et al (2012) A comprehensive review on biodiesel as an alternative energy resource and its characteristics. Renew Sustain Energy Rev 16:2070-2093

15. EIA (2020) Monthly biodiesel production report. In: U.S. Energy Inf. Adm. https://www.eia.gov/biofuels/biodiesel/production/. Accessed 19 May 2020

16. Taufiq-Yap YH, Ahmad Farabi MS, Syazwani ON et al (2020) Sustainable production of bioenergy. In: Innovations in sustainable energy and cleaner environment, Springer, pp 541-561

17. Singh D, Sharma D, Soni SL et al (2020) A review on feedstocks, production processes, and yield for different generations of biodiesel. Fuel 262:116553

18. Sharma AK, Baredar P (2018) Biodiesel: Sources, production, emissions, and policies. In: Sharma A, Shukla A, Aye L (eds) Low carbon energy supply. Springer, Berlin, pp 123-174

19. Karmakar B, Halder G (2019) Progress and future of biodiesel synthesis: advancements in oil extraction and conversion technologies. Energy Convers Manag 182:307-339

20. Chakraborty R, Gupta AK, Chowdhury R (2014) Conversion of slaughterhouse and poultry farm animal fats and wastes to biodiesel: parametric sensitivity and fuel quality assessment. Renew Sustain Energy Rev 29:120-134

21. Khanali M, Mousavi SA, Sharifi M et al (2018) Life cycle assessment of canola edible oil production in Iran: a case study in Isfahan province. J Clean Prod 196:714-725. https://doi. org/10.1016/j.jclepro.2018.05.217

22. Borugadda VB, Goud VV (2012) Biodiesel production from renewable feedstocks: status and opportunities. Renew Sustain Energy Rev 16:4763-4784

23. Najafi B, Faizollahzadeh Ardabili S (2018) Application of ANFIS, ANN, and logistic methods in estimating biogas production from spent mushroom compost (SMC). Resour Conserv Recycl 133:169-178. https://doi.org/10.1016/j.resconrec.2018.02.025

24. Hajjari M, Tabatabaei M, Aghbashlo M, Ghanavati H (2017) A review on the prospects of sustainable biodiesel production: a global scenario with an emphasis on waste-oil biodiesel utilization. Renew Sustain Energy Rev 72:445-464

25. Marchetti JM, Miguel VU, Errazu AF (2007) Possible methods for biodiesel production. Renew Sustain Energy Rev 11:1300-1311

26. Harold S (1997) Industrial vegetable oil: opportunities within the European biodiesel and lubricants markets. Part 2. Marketcharacteristics. Lipid Technol 9:67-70

27. Balat $M$, Balat $H$ (2010) Progress in biodiesel processing. Appl Energy 87:1815-1835

28. Knothe G, Krahl J, Van Gerpen J (2010) The biodiesel handbook, 2nd edn. Elsevier, Amsterdam

29. Lourinho G, Brito P (2015) Advanced biodiesel production technologies: novel developments. Rev Environ Sci Biotechnol 14:287-316

30. Kirubakaran M, Arul Mozhi Selvan V (2018) A comprehensive review of low cost biodiesel production from waste chicken fat. Renew Sustain Energy Rev 82:390-401

31. Gebremariam SN, Marchetti JM (2017) Biodiesel production technologies: review. Energy 5:425-457. https://doi. org/10.3934/ENERGY.2017.3.425
32. Ambat I, Srivastava V, Sillanpää M (2018) Recent advancement in biodiesel production methodologies using various feedstock: a review. Renew Sustain Energy Rev 90:356-369

33. Lin L, Cunshan Z, Vittayapadung S et al (2011) Opportunities and challenges for biodiesel fuel. Appl Energy 88:1020-1031

34. Zahan K, Kano M (2018) Biodiesel production from palm oil, its by-products, and mill effluent: a review. Energies 11:2132. https://doi.org/10.3390/en 11082132

35. Tabatabaei M, Aghbashlo M, Dehhaghi M et al (2019) Reactor technologies for biodiesel production and processing: a review. Prog Energy Combust Sci 74:239-303

36. Sharma YC, Singh B (2009) Development of biodiesel: current scenario. Renew Sustain Energy Rev 13:1646-1651

37. Shahid EM, Jamal Y (2011) Production of biodiesel: a technical review. Renew Sustain Energy Rev 15:4732-4745

38. Saifuddin N, Samiuddin A, Kumaran P (2015) A review on processing technology for biodiesel production. Trends Appl Sci Res 10:1-37. https://doi.org/10.3923/tasr.2015.1.37

39. Rezania S, Oryani B, Park J et al (2019) Review on transesterification of non-edible sources for biodiesel production with a focus on economic aspects, fuel properties and by-product applications. Energy Convers Manag 201:112155

40. Quah RV, Tan YH, Mubarak NM et al (2019) An overview of biodiesel production using recyclable biomass and non-biomass derived magnetic catalysts. J Environ Chem Eng 7:103219. https://doi.org/10.1016/j.jece.2019.103219

41. Alptekin E, Canakci M (2011) Optimization of transesterification for methyl ester production from chicken fat. Fuel 90:2630-2638. https://doi.org/10.1016/j.fuel.2011.03.042

42. Adewale P, Dumont M-J, Ngadi M (2015) Recent trends of biodiesel production from animal fat wastes and associated production techniques. Renew Sustain Energy Rev 45:574-588. https://doi.org/10.1016/j.rser.2015.02.039

43. Ramírez-Verduzco LF, Rodríguez-Rodríguez JE, Jaramillo-Jacob ADR (2012) Predicting cetane number, kinematic viscosity, density and higher heating value of biodiesel from its fatty acid methyl ester composition. Fuel 91:102-111. https://doi. org/10.1016/j.fuel.2011.06.070

44. Yanowitz J, McCormick RL (2009) Effect of biodiesel blends on North American heavy-duty diesel engine emissions. Eur J Lipid Sci Technol 111:763-772. https://doi.org/10.1002/ ejlt.200800245

45. Haas MJ, Scott KM, Alleman TL, McCormick Robert L (2001) Engine performance of biodiesel fuel prepared from soybean soapstock: a high quality renewable fuel produced from a waste feedstock. Energy Fuels 15:1207-1212. https://doi. org/10.1021/EF010051X

46. Mohiddin MN, Saleh AA, Reddy ANR, Hamdan S (2018) A study on chicken fat as an alternative feedstock: biodiesel production, fuel characterisation, and diesel engine performance analysis. Int J Automot Mech Eng 15:5535-5546. https://doi. org/10.15282/ijame.15.3.2018.10.0425

47. Bhatti HN, Hanif MA, Qasim M, Ata-ur-Rehman (2008) Biodiesel production from waste tallow. Fuel 87:2961-2966. https://doi. org/10.1016/j.fuel.2008.04.016

48. Marulanda VF, Anitescu G, Tavlarides LL (2010) Investigations on supercritical transesterification of chicken fat for biodiesel production from low-cost lipid feedstocks. J Supercrit Fluids 54:53-60. https://doi.org/10.1016/j.supflu.2010.04.001

49. Behçet R, Oktay H, Çakmak A, Aydin H (2015) Comparison of exhaust emissions of biodiesel-diesel fuel blends produced from animal fats. Renew Sustain Energy Rev 46:157-165

50. $\mathrm{SCl}$ (2020) Selected results of layer chicken farms census, the year 2017

51. Jayathilakan K, Sultana K, Radhakrishna K, Bawa AS (2012) Utilization of byproducts and waste materials from meat, poultry 
and fish processing industries: a review. J Food Sci Technol 49:278-293. https://doi.org/10.1007/s13197-011-0290-7

52. Sari ÖF, Özdemir S, Celebi A (2016) Utilization and management of poultry slaughterhouse wastes with new methods. In: EurAsia waste management symposium, İstanbul, Turkey

53. Abraham J, Kumar RS, Xavier F, Mathew D (2015) Biodiesel production from broiler chicken Waste. Int J Agric Biosyst Eng 9:1190-1193. https://doi.org/10.5281/ZENODO.1110157

54. Srinivasa Rao K, Ramakrishna A (2015) Cost estimation analysis of biodiesel production from waste chicken fat. Int J Appl Eng Res 10:8863-8870
55. Aristizábal-Marulanda V, Cardona Alzate CA (2019) Methods for designing and assessing biorefineries: review. Biofuels Bioprod Biorefining 13:789-808. https://doi.org/10.1002/bbb.1961

56. Safieddin Ardebili SM, Khademalrasoul A (2018) An analysis of liquid-biofuel production potential from agricultural residues and animal fat (case study: khuzestan Province). J Clean Prod 204:819-831. https://doi.org/10.1016/j.jclepro.2018.09.031

57. NIORDC (2020) Statistical yearbook: petroleum products consumption of energy producer in 2018. Tehran, I.R. Iran

Publisher's Note Springer Nature remains neutral with regard to jurisdictional claims in published maps and institutional affiliations. 